\title{
Modulation of Opioid Receptor Binding by Cis and Trans Fatty Acids
}

\author{
Ann E. Remmers, Gordon L. Nordby, and Fedor Medzihradsky \\ Departments of Biological Chemistry and Pharmacology, The University of Michigan Medical School, \\ Ann Arbor, Michigan, U.S.A.
}

\begin{abstract}
In synaptosomal brain membranes, the addition of oleic acid (cis), elaidic acid (trans), and the cis and trans isomers of vaccenic acid, at a concentration of $0.87 \mu \mathrm{mol}$ of lipid/mg of protein, strongly reduced the $B_{\max }$ and, to a lesser degree, the binding affinity of the $\mu$-selective opioid $\left[{ }^{3} \mathrm{H}\right] \mathrm{Tyr}-$ D-Ala-Gly-(Me)Phe-Gly-ol ([ $\left.\left.{ }^{3} \mathrm{H}\right] \mathrm{DAMGO}\right)$. At comparable membrane content, the cis isomers of the fatty acids were more potent than their trans counterparts in inhibiting ligand binding and in decreasing membrane microviscosity, both at the membrane surface and in the core. However, trans-vaccenic acid affected opioid receptor binding in spite of just marginally altering membrane microviscosity. If the receptors were uncoupled from guanine nucleotide regulatory protein, an altered inhibition profile was obtained: the impairment of $K_{\mathrm{D}}$ by the fatty acids was enhanced and that of $B_{\max }$ reduced. Receptor interaction of the $\delta$-opioid $\left[{ }^{3} \mathrm{H}\right]\left(\mathrm{D}-\mathrm{Pen}^{2}, \mathrm{D}-\right.$ $\left.\mathrm{Pen}^{5}\right)$ enkephalin was modulated by lipids to a greater extent
\end{abstract}

than that of $\left[{ }^{3} \mathrm{H}\right] \mathrm{DAMGO}$ : saturable binding was abolished by both oleic and elaidic acids. The binding of $\left[{ }^{3} \mathrm{H}\right]$ naltrexone was less susceptible to inhibition by the fatty acids, particularly in the presence of sodium. In the absence of this cation, however, cis-vaccenic acid abolished the low-affinity binding component of $\left[{ }^{3} \mathrm{H}\right]$ naltrexone. These findings support the membrane model of opioid receptor sequestration depicting different ionic environments for the $\mu$ - and $\delta$-binding sites. The results of this work show distinct modulation of different types and molecular states of opioid receptor by fatty acids through mechanisms involving membrane fluidity and specific interactions with membrane constituents. Key Words: $\mu$ - and $\delta$-opioid receptors-Ligand-receptor interaction-Cis and trans fatty acids-Membrane lipid content-Membrane microviscosity. Remmers A. E. et al. Modulation of opioid receptor binding by cis and trans fatty acids. J. Neurochem. 55, 1993-2000 (1990).
Analogous to the dependence of soluble enzymes on the composition and characteristics of their aqueous milieu, the activity of functional membrane proteins is influenced by properties of the lipid bilayer (Carruthers and Melchior, 1986). The function of surface receptors was shown to be modulated by the physical property of the membrane: for example, coupling to adenylate cyclase of the $\beta$-adrenergic receptor, but not of adenosine receptor, in turkey erythrocytes was enhanced by decreasing membrane microviscosity (Rimon et al., 1978). On the other hand, in these cells, incorporated phosphatidylinositol uncoupled catecholamine binding from adenylate cyclase by a mechanism other than membrane fluidity (McOsker et al., 1983). The sensitivity of opioid receptors to lipids has been well documented. Ligand binding ( $\mathrm{Lin}$ and Simon, 1978; Abood et al., 1980) and receptor coupling to adenylate cyclase (Law et al., 1983) and low- $K_{\mathrm{m}}$ GTPase (Lazar and Medzihradsky, 1990) were inhibited by phospholipase treatment, and unsaturated fatty acids decreased opioid receptor binding in cultured NG108-15 cells (Ho and Cox, 1982; McGee and Kenimer, 1982). Acidic phospholipids containing polyunsaturated fatty acids enhanced ligand binding to the partially purified $\mu$-opioid receptor (Hasegawa et al., 1987), whereas phospholipids inhibited opioid receptor binding in rat brain membranes (Remmers and Medzihradsky, 1987).

Exogenous fatty acids were shown to alter membrane structure and function (e.g., Stubbs and Smith, 1984), thereby exhibiting stereospecificity (Orly and Schramm, 1975; Seifert et al., 1988). In accord with our goal to characterize the modulation of opioid receptors by membrane lipids (Medzihradsky, 1989), we
Received December 21, 1989; revised manuscript received May 23, 1990; accepted May 25, 1990.

Address correspondence and reprint requests to Dr. F. Medzihradsky at Department of Biological Chemistry, The University of Michigan Medical School, 6440 Medical Science Building I, Ann Arbor, MI 48109, U.S.A.
Abbreviations used: DAMGO, Tyr-D-Ala-Gly-(Me)Phe-Gly-ol; DPH, diphenylhexatriene; DPDPE, (D-Pen ${ }^{2}, D-P^{5}$ )enkephalin; G protein, guanine nucleotide regulatory protein; GLC, gas-liquid chromatography; GTP- $\gamma-\mathrm{S}$, guanosine 5'-O-(3-thiotriphosphate); TMA-DPH, trimethylammonium derivative of diphenylhexatriene. 
now report the use of cis and trans fatty acids to discern mechanisms by which these compounds affect opioid ligand binding. The results show that the fatty acids inhibited opioid receptor binding in proportion to their membrane fluidizing property, but also acted by direct interaction with the phospholipid bilayer. The effect was different at the $\mu$ - and $\delta$-receptors, and was influenced by receptor conformation and state of coupling to $\mathrm{G}$ protein.

\section{MATERIALS AND METHODS}

\section{Materials}

Tritiated Tyr-D-Ala-Gly-(Me)Phe-Gly-ol (DAMGO) and (D-Pen ${ }^{2}, \mathrm{D}-\mathrm{Pen}^{5}$ )enkephalin (DPDPE) were purchased from Amersham (Arlington Heights, IL, U.S.A.) and New England Nuclear (Boston, MA, U.S.A.), respectively. $\left[{ }^{3} \mathrm{H}\right]$ Naltrexone was generously provided by the National Institute on Drug Abuse. DPDPE was a gift from Dr. H. I. Mosberg. DAMGO was purchased from Peninsula Laboratories (Belmont, CA, U.S.A.), and naltrexone was supplied by the Drug Abuse Basic Research Center at the University of Michigan. cis-9-Octadecenoic acid (oleic acid), trans-9-octadecenoic acid (elaidic acid), and cis- and trans-11-octadecenoic acids (vaccenic acids) were obtained from Sigma (St. Louis, MO, U.S.A.). Diphenylhexatriene (DPH) and its charged trimethylammonium derivative (TMA-DPH) were purchased from Molecular Probes (Junction City, OR, U.S.A.). Fatty acid methyl ester standards were purchased from Serdary Laboratories (London, Ontario, Canada) and Alltech (Deerfield, IL, U.S.A.). The gas-liquid chromatography (GLC) packing Silar 10-C on 100/120 mesh Gas Chrom-II was obtained from Alltech, and $\mathrm{BF}_{3}$-methanol reagent was bought from Pierce (Rockford, IL, U.S.A.).

\section{Membrane preparation}

A crude synaptosomal preparation was isolated from cortices of male Sprague-Dawley rats weighing $180-200 \mathrm{~g}$ as described (Cahill and Medzihradsky, 1976). Briefly, cerebral cortices were dissected free of white matter at $4^{\circ} \mathrm{C}$ and homogenized in $0.32 \mathrm{M}$ sucrose at a concentration of $10 \%(\mathrm{wt} /$ vol). Tissue disruption was carried out at $500 \mathrm{rpm}$ in a PotterElvehjem homogenizer with a Teflon pestle. The supernatant resulting from the centrifugation at $1,000 \mathrm{~g}$ for $10 \mathrm{~min}$ was centrifuged again at $15,000 \mathrm{~g}$ for $20 \mathrm{~min}$. The upper part of the pellet, consisting of a fluffy light beige layer, was resuspended in $50 \mathrm{~m} M$ Tris, $\mathrm{pH}$ 7.4. The suspension was centrifuged at $15,000 \mathrm{~g}$ for $20 \mathrm{~min}$ to remove any remaining sucrose, resuspended in $50 \mathrm{mM}$ Tris- $\mathrm{HCl}, \mathrm{pH} 7.4$, at a protein concentration of approximately $1 \mathrm{mg} / \mathrm{ml}$, and stored at $-70^{\circ} \mathrm{C}$.

\section{Determination of protein}

The methods according to Lowry et al. (1951) and Bradford (1976) were used, with bovine serum albumin as a standard. In both procedures, the membrane protein was solubilized initially with $1 \mathrm{M} \mathrm{NaOH}$ for $30 \mathrm{~min}$ at $25^{\circ} \mathrm{C}$.

\section{Measurement of membrane microviscosity}

The fluorescent probes DPH (solution in $N, N$-dimethylformamide) and TMA-DPH (solution in tetrahydrofuran) were incubated with membranes at $25^{\circ} \mathrm{C}$ for $30 \mathrm{~min}$ and 60 min, respectively (Shinitzky and Barenholz, 1978; Kuhry et al., 1983). The molar ratio of probe to membrane phospholipid was approximately $1: 500$. Subsequently, fluorescence polarization was measured in an SLM spectrofluorometer at wavelengths of $360 \mathrm{~nm}$ and $430 \mathrm{~nm}$ (DPH) and $340 \mathrm{~nm}$ and $450 \mathrm{~nm}$ (TMA-DPH) for excitation and emission, respectively.

\section{Membrane modification with fatty acids}

The fatty acids were added to membrane suspensions in the form of an ethanol solution at a maximal alcohol concentration of $0.4 \%$. In control experiments, membranes were incubated with ethanol alone. Following incubation for 20 $\min$ at $25^{\circ} \mathrm{C}$, the membranes were centrifuged through 0.5 $M$ sucrose, $\mathrm{pH} 7.4$, at $100,000 \mathrm{~g}$ for $20 \mathrm{~min}$ to remove sticking lipid. Membrane lipids were extracted with chloroform/ methanol (2:1) according to Radin (1969). Methylation of fatty acids was carried out using $14 \% \mathrm{BF}_{3}$ in methanol as described (Morrison and Smith, 1964). The methyl esters were quantitated by GLC in a Hewlett-Packard 402B gas chromatograph with a flame ionization detector (Lazar and Medzihradsky, unpublished observations). The column ( $6 \mathrm{ft}$ $\times \frac{1}{4}$ in o.d.) was packed with $10 \%$ Silar $10-\mathrm{C}$ and operated with linear programming from $180^{\circ} \mathrm{C}$ at $2^{\circ} \mathrm{C} / \mathrm{min}$ using nitrogen as the carrier gas. The peak heights were quantitated using standards of fatty acid methyl esters.

\section{Ligand binding}

Ligand binding was carried out at $25^{\circ} \mathrm{C}$ as described (Fischel and Medzihradsky, 1981) in the absence and presence of $5 \mu M$ guanosine $5^{\prime}-O$-(3-thiotriphosphate) (GTP- $\left.\gamma-\mathrm{S}\right)$ or $150 \mathrm{mM} \mathrm{NaCl}$. These concentrations of the nucleotide and sodium were shown in our study to affect maximally opioid agonist and antagonist binding, respectively. Specific binding of the radiolabeled opioids was determined in the absence and presence of an excess of the respective unlabeled ligand. These concentrations were $2 \mu M$ for $\left[{ }^{3} \mathrm{H}\right] \mathrm{DAMGO}, 5 \mu M$ for $\left[{ }^{3} \mathrm{H}\right] \mathrm{DPDPE}$, and $1 \mu M$ for $\left[{ }^{3} \mathrm{H}\right]$ naltrexone. Binding equilibrium was established at $80 \mathrm{~min}, 60 \mathrm{~min}$, and $30 \mathrm{~min}$ for radiolabeled DAMGO, DPDPE, and naltrexone, respectively. The binding selectivity of the ligands was determined previously (Clark et al., 1988).

\section{Statistical analysis of the data}

For the analysis of ligand binding, the NONLIN module in the SYSTAT statistical program (Wilkinson, 1988) was used. It is a generalized nonlinear least squares regression program that was applied to fit a two-site binding model. In some experiments, only a one-site model could be supported by the data. Data sets from three to five replicate experiments were combined to improve the regression analysis by increasing variability. Because a valid regression depends upon normally distributed within-set random errors, the between-set errors were assigned to additional regression parameters that represented each of the replicate experiments. The weighed residual sum of squares thus reflected random experimental error.

Following the initial regression, the residuals were displayed in a normal probability plot, using the GRAPH module, to evaluate both their magnitude and their departure from expected, normally distributed residuals. All data reported are based upon regressions for which the distribution of residuals was not different from a normal distribution. The corresponding standard error of the mean was computed within NONLIN from the residual sum of squares of the regression. The hypothesis that two parameters are equal for different 

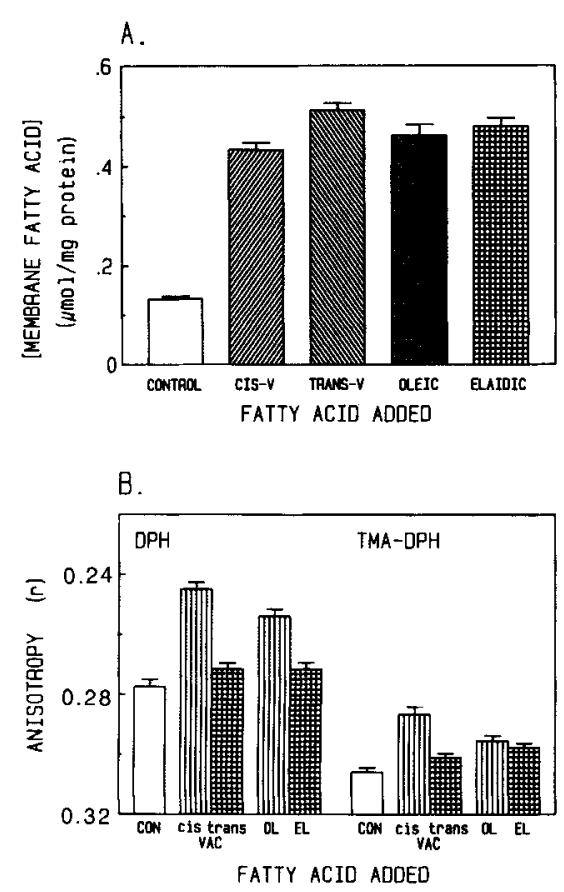

FIG. 1. Membrane microviscosity and fatty acid content. A: Synaptosomal brain membranes were modified by the addition of 0.87 $\mu \mathrm{mol}$ of fatty acid/mg of protein. Following lipid extraction, methy esters of fatty acids were formed and analyzed by GLC as described under Materials and Methods. Shown are the mean membrane contents of fatty acids $( \pm S D$ ) obtained in three to four experiments. B: Following incorporation of DPH and TMA-DPH into control and fatty acid-modified membranes, their fluorescence polarization was determined. The results are expressed as anisotropy values $(r)$ where $r=\left(I_{0}-I_{90}\right) /\left(I_{0}+2 I_{90}\right)$, and $I_{0}$ and $I_{90}$ represent the intensities of light when polarizers were in a parallel or perpendicular orientation, respectively. Differences in the efficiency of transmitting vertically and horizontally polarized light were corrected for by determining the polarization ratio $\left(l_{0} / /_{90}\right)$ using horizontally rather than vertically polarized excitation light. The advantage of expressing fluorescence polarization as anisotropy is the additive nature of the latter. Shown are the means \pm SD of four experiments, each carried out in quadruplicate. The results of these two series of experiments were subjected to a one-way analysis of variance as described under Materials and Methods. CON, control; EL, elaidic acid; OL, oleic acid; $V$ or VAC, vaccenic acid.

membrane treatments was tested by the usual statistic using the parameter mean and the standard error of the mean (see legends to Tables 1 and 2).

The data on membrane microviscosity and membrane content of fatty acids were analyzed by the ANOVA module, a true one-way least squares analysis of variance in the SYSTAT statistical software program (Wilkinson, 1988). When a significant fatty acid effect was identified by the ANOVA analysis, pairwise contrasts were made to identify specifically which fatty acid treatment effects were significant. Grouped contrasts, such as the combined cis versus trans fatty acid effects, were also tested by contrast options within ANOVA.

\section{RESULTS}

In initial experiments, the incorporation of the four fatty acids into brain membranes and their effect on membrane microviscosity were determined. At 0.87 $\mu \mathrm{mol}$ of added lipid/mg of membrane protein, a concentration causing substantial inhibition of opioid binding (see Fig. 2), the incremental membrane content of these compounds corresponded to approximately $39 \%$ of the added fatty acid (Fig. 1A). There was no significant difference in the incorporation of oleic and elaidic acids, but the membrane content of $c i s$-vaccenic acid was 3\% lower than its trans counterpart. Despite this difference, cis-vaccenic acid was more potent in modulating opioid receptor binding. Microviscosity in the hydrophobic membrane core (assessed by DPH) was strongly decreased by cis fatty acids and marginally by the trans isomers (Fig. 1B). Within the cis series, vaccenic acid reduced microviscosity to a greater extent. At the membrane surface (assessed by the cation TMA-DPH), the lipid-induced changes in microviscosity were smaller, and the difference in respective potencies between cis and trans fatty acids was diminished. This was particularly the case for oleic and elaidic acids, which displayed similar membrane fluidizing properties (Fig. 1B).

Determined at a single $\left[{ }^{3} \mathrm{H}\right]$ DAMGO concentration of $10 \times K_{\mathrm{D}}$, all the fatty acids decreased specific binding in a concentration-dependent manner (Fig. 2). The cis

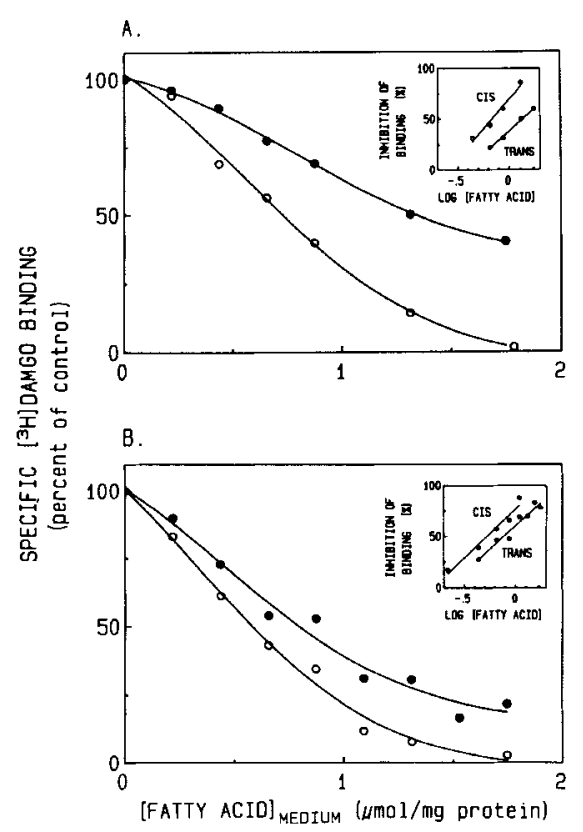

FIG. 2. Inhibition of specific $\left[{ }^{3} \mathrm{H}\right] \mathrm{DAMGO}$ binding by fatty acids. Membranes were treated with cis- $(O)$ and trans- $(\Theta)$ vaccenic acids (A) or oleic $(O)$ and elaidic ( $\bullet$ ) acids (B), as described under Materials and Methods. Subsequently, the specific binding of $4 \mathrm{nM}$ [ $\left.{ }^{3} \mathrm{H}\right] \mathrm{DAMGO}$ at equilibrium was determined. Results are expressed as percent of control binding. Ethanol added to control membranes up to $0.5 \%$ did not affect ligand binding. Insets: The inhibition of $\left[{ }^{3} \mathrm{H}\right] \mathrm{DAMGO}$ binding is plotted against the log concentration of fatty acids. The respective $\mathrm{EC}_{50}$ values (in $\mu \mathrm{mol} / \mathrm{mg}$ of membrane protein) were as follows: cis-vaccenic, 0.71; trans-vaccenic, 1.37; oleic, 0.55 , elaidic, 0.79 . Shown are mean values of three experiments carried out in duplicate. 
isomers were more effective than their trans counterparts: the $\mathrm{EC}_{50}$ values (in $\mu \mathrm{mol} / \mathrm{mg}$ of protein) for $\mathrm{cis}$ and trans-vaccenic acid were 0.71 and 1.37 , and for oleic and elaidic acids 0.55 and 0.79 , respectively (Fig. 2 , insets). In accord with its significant effect on membrane surface microviscosity, elaidic acid strongly inhibited opioid receptor binding. Thus, in contrasting the effects of cis and trans fatty acids, there was a positive correlation between decreased binding and reduced microviscosity, particularly when the latter was measured at the membrane surface. This relationship was highlighted by the limited effect of trans-vaccenic acid in altering microviscosity and ligand binding (Fig. 2A and Table 1).

The effect of lipids on ligand binding was evaluated further by nonlinear regression analysis. The binding of the $\mu$-selective opioid [ $\left.{ }^{3} \mathrm{H}\right] \mathrm{DAMGO}$ in unmodified membranes revealed one population of saturable sites with a $K_{\mathrm{D}}$ of $0.4 \mathrm{n} M$ and a $B_{\max }$ of $151 \mathrm{fmol} / \mathrm{mg}$ of protein in the absence of GTP- $\gamma-\mathrm{S}$, and values of 1.4 $\mathrm{n} M$ and $152 \mathrm{fmol} / \mathrm{mg}$ of protein in the presence of the nucleotide (Table 1). Following treatment, both the affinity and capacity of binding were reduced (Fig. 3). Oleic and elaidic acids were more effective than the vaccenic acids in reducing $B_{\max }$ and increasing $K_{\mathrm{D}}$ values. Of particular interest is the fact that these parameters were affected differentially by fatty acid modu- lation of the uncoupled receptor obtained in the presence of GTP- $\gamma-S$ (Fig. 4A and Table 1): whereas the rise in $K_{\mathrm{D}}$ values was enhanced, the decrease in $B_{\max }$ values was diminished.

In the presence of GTP- $\gamma-\mathrm{S},\left[{ }^{3} \mathrm{H}\right] \mathrm{DPDPE}$ binding was characterized by one population of saturable sites with $K_{\mathrm{D}}$ and $B_{\max }$ values of $2.7 \mathrm{n} M$ and $45 \mathrm{fmol} / \mathrm{mg}$ of protein, respectively (Table 1 ). Both pairs of fatty acid isomers strongly reduced the affinity and extent of binding of this $\delta$-ligand (Fig. 4B and Table 1). Their effect was much more pronounced than at the $\mu$-site: oleic and elaidic acids totally suppressed the specific binding of $\left[{ }^{3} \mathrm{H}\right] \mathrm{DPDPE}$. As with $\mu$-opioid binding, cisvaccenic acid affected both the $K_{\mathrm{D}}$ and $B_{\max }$ values of ligand binding, whereas trans-vaccenic acid primarily decreased the binding affinity of $\left.{ }^{3} \mathrm{H}\right] D P D P E$ (Table 1 ).

In the absence and presence of sodium, the binding of $\left[{ }^{3} \mathrm{H}\right]$ naltrexone revealed two populations of saturable binding sites (Fig. 5 and Table 2). We have observed recently that in rat brain membranes this heterogeneity reflects interaction with $\mu$ - and $\delta$-opioid receptors; in the presence of $\mu$-or $\delta$-selective opioids, $\left[{ }^{3} \mathrm{H}\right]$ naltrexone binding was monophasic with only the low- or highaffinity component, respectively, remaining (Remmers and Medzihradsky, unpublished observations). Similar findings were obtained previously with the nonselective opioid antagonist $\left[{ }^{3} \mathrm{H}\right]$ diprenorphine in guinea pig

TABLE 1. Parameters of agonist binding

\begin{tabular}{|c|c|c|c|c|c|c|}
\hline \multirow{2}{*}{$\begin{array}{l}\text { Fatty acid } \\
\text { added }^{a}\end{array}$} & \multicolumn{2}{|c|}{$K_{\mathrm{D}}(\mathrm{n} M)$} & \multicolumn{2}{|c|}{$\begin{array}{c}B_{\max } \\
\text { (fmol/mg of protein) }\end{array}$} & \multicolumn{2}{|c|}{$\mathrm{n}$} \\
\hline & - GTP- $\gamma-S$ & $+\mathrm{GTP}-\gamma-\mathrm{S}$ & $-\mathrm{GTP}-\gamma-\mathrm{S}$ & $+\mathrm{GTP}-\gamma-\mathrm{S}$ & $-\mathrm{GTP}-\gamma-\mathrm{S}$ & $+\mathrm{GTP}-\boldsymbol{\gamma}-\mathrm{S}$ \\
\hline \multicolumn{7}{|l|}{$\left[{ }^{3} \mathrm{H}\right] \mathrm{DAMGO}$} \\
\hline None & $\begin{array}{c}0.41 \\
(0.01)\end{array}$ & $\begin{array}{r}1.43 \\
(0.05)\end{array}$ & $\begin{array}{l}150.93 \\
(0.84)\end{array}$ & $\begin{array}{l}151.98 \\
(1.33)\end{array}$ & 76 & 101 \\
\hline cis-Vaccenic & $\begin{array}{c}0.66 \\
(0.03)\end{array}$ & $\begin{array}{r}7.51 \\
(0.49)\end{array}$ & $\begin{array}{r}70.45 \\
(1.21)\end{array}$ & $\begin{array}{l}98.15 \\
(2.92)\end{array}$ & 33 & 39 \\
\hline trans-Vaccenic & $\begin{array}{c}0.45 \\
(0.02)\end{array}$ & $\begin{array}{r}4.38 \\
(0.18)\end{array}$ & $\begin{array}{l}111.98 \\
(1.10)\end{array}$ & $\begin{array}{l}157.05 \\
(2.24)\end{array}$ & 30 & 45 \\
\hline Oleic & $\begin{array}{l}1.65 \\
(0.15)\end{array}$ & $\begin{array}{l}10.11 \\
(1.03)\end{array}$ & $\begin{array}{r}49.71 \\
(2.17)\end{array}$ & $\begin{array}{l}63.76 \\
(3.11)\end{array}$ & 28 & 52 \\
\hline Elaidic & $\begin{array}{c}0.83 \\
(0.05)\end{array}$ & $\begin{array}{r}8.29 \\
(0.50)\end{array}$ & $\begin{array}{r}67.06 \\
(1.61)\end{array}$ & $\begin{array}{r}79.87 \\
(2.30)\end{array}$ & 27 & 46 \\
\hline \multicolumn{7}{|l|}{$\left[{ }^{3} \mathbf{H}\right]$ DPDPE } \\
\hline None & & $\begin{array}{r}2.66 \\
(0.17)\end{array}$ & & $\begin{array}{l}44.71 \\
(0.76)\end{array}$ & & 78 \\
\hline cis-Vaccenic & & $\begin{array}{l}13.32 \\
(6.14)\end{array}$ & & $\begin{array}{r}8.90 \\
(2.21)\end{array}$ & & 37 \\
\hline trans-Vaccenic & & $\begin{array}{l}16.03 \\
(2.12)\end{array}$ & & $\begin{array}{l}35.76 \\
(2.50)\end{array}$ & & 48 \\
\hline Oleic & & ND & & ND & & 28 \\
\hline Elaidic & & ND & & ND & & 25 \\
\hline
\end{tabular}

The binding parameters at equilibrium were obtained from nonlinear regression analysis using a receptor model with one or two binding sites. Shown are parameter means and the standard error of the means (in parentheses) computed from the total number, $n$, of data points obtained in three to five experiments, as described under Materials and Methods. All the values listed in this table are different from the respective controls at the $5 \%$ level of significance. The experiments were carried out in the absence (-) and presence $(+)$ of $5 \mu M$ GTP- $\gamma-S$. ND, saturable binding not detected.

${ }^{a}$ Membrane modification was carried out as described under Materials and Methods. The fatty acids were added at the concentration of $0.87 \mu \mathrm{mol} / \mathrm{mg}$ of membrane protein. 

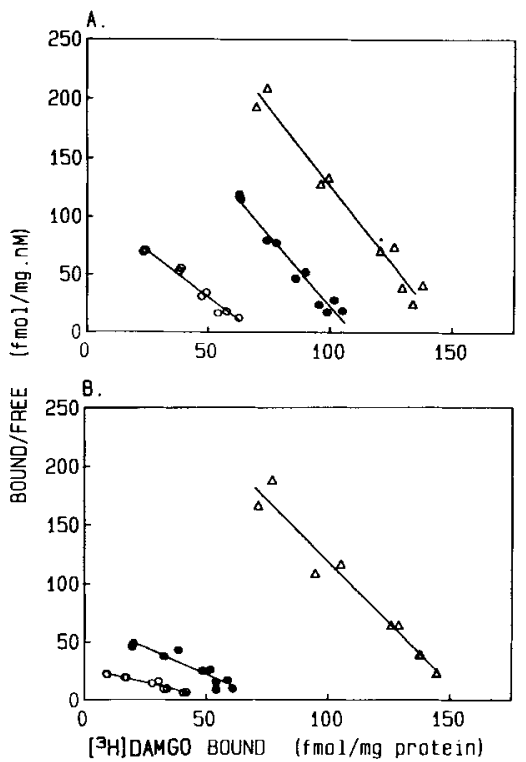

FIG. 3. Scatchard plots of [ $\left.{ }^{3} \mathrm{H}\right] \mathrm{DAMGO}$ binding. Membranes were treated with fatty acids, added at a concentration of $0.87 \mu \mathrm{mol} /$ $\mathrm{mg}$ of membrane protein, as described under Materials and Methods. Subsequently, the equilibrium binding of [ $\left.{ }^{3} \mathrm{H}\right] \mathrm{DAMGO}$ in control membranes $(\triangle)$ and membranes modified with cis- $(O)$ and trans$(\oplus)$ vaccenic acid $(A)$ or oleic $(O)$ and elaidic $(\Theta)$ acids $(B)$ was determined. Plotted are data points from a representative experiment. The binding parameters, $K_{\mathrm{D}}$ and $B_{\max }$, from three to five experiments, were obtained by nonlinear regression analysis and are listed together with statistical information in Table 1.

brain membranes; in the presence of the $\delta$-selective opioid ICI 174,864, its binding was monophasic and $\mu$-specific (Werling et al., 1988). Compared to their inhibition of opioid agonist binding, the fatty acids were less effective in altering the binding of $\left[{ }^{3} \mathrm{H}\right]$ naltrexone, particularly in the presence of $\mathrm{NaCl}$. Whereas all binding parameters of $\left[{ }^{3} \mathrm{H}\right] D A M G O$ and $\left[{ }^{3} \mathrm{H}\right] D P D P E$ were different following fatty acid treatment (Table 1), only two of these constants for $\left[{ }^{3} \mathrm{H}\right]$ naltrexone were significantly different from controls (Table 2). However, in the absence of sodium, cis-vaccenic acid selectively abolished the low-affinity binding component of $\left[{ }^{3} \mathrm{H}\right]$ naltrexone, while limiting its effect at the high-affinity site to an increased $K_{\mathrm{D}}$ value (Table 2 ).

\section{DISCUSSION}

As shown by their numerous acute and chronic effects, fatty acids modulate manifold membrane functions (e.g., Stubbs and Smith, 1984). A possible common mechanism by which these diverse compounds may act involves their ability to alter membrane fluidity. In producing this effect, the potency of a fatty acid is generally proportional to the degree of unsaturation and number of cis double bonds in the molecule. In addition to this general mode of action, structural elements of membrane lipids have been shown to modulate the activity of intrinsic proteins in a specific manner (Carruthers and Melchior, 1988). Despite extensive evidence for the correlation of membrane fluidity and physiological activity, including membrane function (e.g., Kates and Manson, 1984; Aloia et al., 1988), a role of this membrane property as a primary molecular phenomenon has rarely been demonstrated. Chronic treatment of neural cells with free fatty acids appreciably reduced the binding capacity of opioid ligands (Ho and Cox, 1982; McGee and Kenimer, 1982). The extent of these effects correlated with the degree of fatty acid unsaturation. Although the involvement of membrane fluidity was postulated, it was not assessed experimentally.

In the present work, we have used two pairs of fatty acid enantiomers of different chemical structure, but with the same degree of unsaturation, to study the mechanisms by which these compounds influence ligand-receptor interactions. Throughout the study, the cis fatty acids, at comparable membrane content, were more potent than the transisomers in decreasing microviscosity and in reducing the binding affinity and $B_{\max }$ of $\left[{ }^{3} \mathrm{H}\right] \mathrm{DAMGO}$. In the trans series, elaidic acid with a relatively strong fluidizing effect at the membrane surface inhibited ligand binding to a greater extent than did trans-vaccenic acid. On the other hand, although just marginally affecting membrane micro-
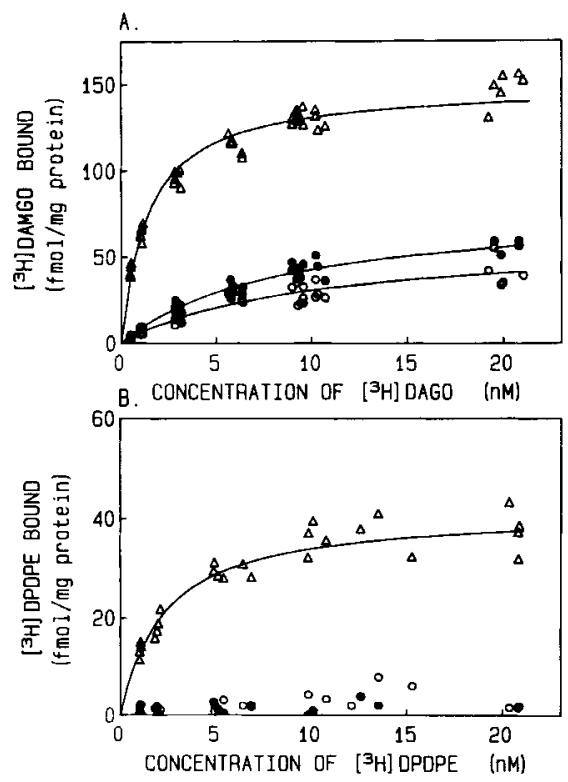

FIG. 4. Equilibrium binding of $\left[{ }^{3} \mathrm{H}\right] \mathrm{DAMGO}(\mathbf{A})$ and $\left[{ }^{3} \mathrm{H}\right] \mathrm{DPDPE}(\mathbf{B})$ in the presence of GTP- $\gamma-\mathrm{S}$. Membranes were treated with fatty acids, added at a concentration of $0.87 \mu \mathrm{mol} / \mathrm{mg}$ of membrane protein, as described under Materials and Methods. Subsequently, equilibrium binding of $\left[{ }^{3} \mathrm{H}\right] \mathrm{DAMGO}(\mathrm{A})$ and $\left[{ }^{3} \mathrm{H}\right] \mathrm{DPDPE}(\mathrm{B})$ in the presence of $5 \mu M$ GTP- $\gamma$-S was determined in control membranes $(\Delta)$ and membranes modified with oleic $(O)$ and elaidic $(\Theta)$ acids. Shown are data points from three to six experiments. The binding parameters and statistical information, obtained by nonlinear regression analysis as described under Materials and Methods, are listed in Table 1. 

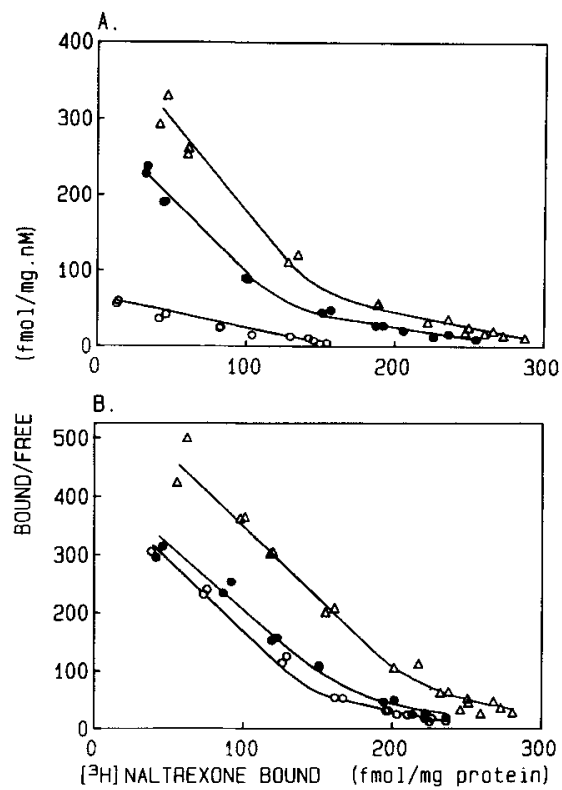

FIG. 5. Scatchard plots of $\left[{ }^{3} \mathrm{H}\right]$ naltrexone binding. Membranes were treated with fatty acids, added at a concentration of 0.87 $\mu \mathrm{mol} / \mathrm{mg}$ of membrane protein, as described under Materials and Methods. Subsequently, the equilibrium binding of $\left[{ }^{3} \mathrm{H}\right]$ naltrexone in the absence (A) and presence (B) of $150 \mathrm{mM} \mathrm{NaCl}$ was determined in control membranes $(\Delta)$ and membranes modified with cis- $(O)$ and trans- $(\bullet)$ vaccenic acid. Shown are the results from a representative experiment. The binding parameters and statistical data are listed in Table 2.

viscosity, trans-vaccenic acid still impaired opioid receptor binding. This observation indicates either that fatty acids also act by a mechanism separate from that involving membrane fluidity, or that the small change in microviscosity (Fig. 1B) does not reflect a more pronounced effect in the vicinity of the receptor. The limiting resolution of the applied fluorescence technique prevents us from excluding localized changes in membrane microviscosity resulting from the partitioning of the fatty acids, including the trans isomers, into discrete domains of the lipid bilayer (Karnovsky et al., 1982). One membrane area of primary importance for receptor function is the lipid-protein interface. The assessment of microviscosity in this boundary layer, in contrast to the analysis of bulk fluidity, should reveal the intimate relationship between this membrane property and opioid receptor mechanisms. Such experiments are in preparation. In this regard, it is of interest that the determination of microviscosity at the membrane surface with the cationic probe TMA-DPH disclosed a fluidizing property of elaidic acid not observed with DPH.

The responses of opioid receptor to lipid modulation were altered following its uncoupling from $G$ protein by GTP- $\gamma-S$ treatment. In general, the free receptor was more susceptible to fatty acid actions. A specific lipid requirement for the activation of $\mathrm{G}_{\mathrm{s}}$ by the $\beta$ adrenergic receptor in erythrocyte membranes has been reported (Ben-Arie et al., 1988), and the inhibition of opioid receptor coupling to brain GTPase by phospholipase $\mathrm{A}_{2}$ was described (Lazar and Medzihradsky, 1990). Although these observations indicate a function for lipids in receptor-effector coupling, mechanistic conclusions are difficult to reach, considering the loss of bilayer sidedness during membrane isolation. An approach to assess differentially the role of lipids at the membrane surfaces and in its core has been described recently (Medzihradsky, 1989).

The finding that fatty acids affected (although with

TABLE 2. Parameters of antagonist binding

\begin{tabular}{|c|c|c|c|c|c|c|}
\hline Fatty acid $^{a}$ & $\mathrm{NaCl}^{b}$ & $K_{\mathrm{D} 1}(\mathrm{n} M)$ & $K_{\mathrm{D} 2}(\mathrm{n} M)$ & $\begin{array}{c}B_{\max 1} \\
\text { (fmol/mg of protein) }\end{array}$ & $\begin{array}{c}B_{\max 2} \\
\text { (fmol/mg of protein) }\end{array}$ & $\mathbf{n}$ \\
\hline \multicolumn{7}{|l|}{$\left[{ }^{3} \mathrm{H}\right]$ Naltrexone } \\
\hline None & - & $\begin{array}{l}0.38 \\
(0.07)\end{array}$ & $\begin{array}{c}6.98 \\
(3.45)\end{array}$ & $\begin{array}{l}153.78 \\
(20.56)\end{array}$ & $\begin{array}{l}163.90 \\
(11.86)\end{array}$ & 71 \\
\hline$c i s$-Vaccenic & - & $\begin{array}{l}3.06^{c} \\
(0.14)\end{array}$ & ND & $\begin{array}{c}165.55 \\
(3.08)\end{array}$ & ND & 48 \\
\hline trans-Vaccenic & - & $\begin{array}{l}0.56 \\
(0.09)\end{array}$ & $\begin{array}{c}7.17 \\
(2.21)\end{array}$ & $\begin{array}{l}133.90 \\
(20.65)\end{array}$ & $\begin{array}{l}149.73 \\
(16.91)\end{array}$ & 52 \\
\hline None & + & $\begin{array}{l}0.39 \\
(0.03)\end{array}$ & $\begin{array}{l}5.11 \\
(3.12)\end{array}$ & $\begin{array}{l}218.23 \\
(18.65)\end{array}$ & $\begin{array}{r}90.51 \\
(13.18)\end{array}$ & 70 \\
\hline$c i s$-Vaccenic & + & $\begin{array}{l}0.40 \\
(0.04)\end{array}$ & $\begin{array}{l}7.29 \\
(2.74)\end{array}$ & $\begin{array}{l}152.16^{c} \\
(11.93)\end{array}$ & $\begin{array}{r}114.98 \\
(7.70)\end{array}$ & 54 \\
\hline trans-Vaccenic & + & $\begin{array}{l}0.37 \\
(0.08)\end{array}$ & $\begin{array}{c}3.84 \\
(2.78)\end{array}$ & $\begin{array}{l}195.72 \\
(39.88)\end{array}$ & $\begin{array}{l}130.70 \\
(25.92)\end{array}$ & 36 \\
\hline
\end{tabular}

The binding parameters at equilibrium were obtained from nonlinear regression analysis using a receptor model with one or two binding sites, as described under Materials and Methods. Shown are parameter means and the standard error of the means (in parentheses) computed from the total number, $n$, of data points obtained in three to five experiments, as described under Materials and Methods. ND, saturable binding not detected.

${ }^{a}$ Membrane modification was carried out as described under Materials and Methods. The fatty acids were added at the concentration of $0.87 \mu \mathrm{mol} / \mathrm{mg}$ of membrane protein.

${ }^{b}$ The assay medium in some experiments contained $150 \mathrm{mM} \mathrm{NaCl}(+)$ and in all experiments $5 \mu M \mathrm{GTP}-\gamma-\mathrm{S}$.

${ }^{c}$ Value is different from control at the $5 \%$ level of significance. 
considerable quantitative differences) the opioid receptor in its free and coupled states (Table 1), as well as its agonist or antagonist conformation (Table 2), suggests that the inhibitory action of these compounds involves a general perturbation of the lipid bilayer, resulting in altered membrane microviscosity. As shown, hydrogen bond formation between the fatty acid carboxyl group and phosphate residues in the phospholipid matrix results in diminished repulsion of the charged head groups in the bilayer (Ortiz and GomezFernandez, 1987). In addition, because of steric hindrance, the cis isomers disturb the lipid packing density and, thus, strongly affect membrane microviscosity. A reciprocal relationship between decreasing membrane microviscosity and availability of ligand binding sites for some receptors, including serotonergic, $\beta$-adrenergic, and opioid, was interpreted by the concept of vertical displacement of membrane proteins (Shinitzky, 1984). It is reasonable to expect that altered receptor positioning in the membrane would affect, in addition to $B_{\max }$, access of the ligand to the binding site and, thus, $K_{\mathrm{D}}$. The differentiated profile of fatty acid action, e.g., preferential inhibition of opioid agonist binding and higher potency of the cis acids, ruled out receptor solubilization by detergent-like effects as the underlying mechanism. Furthermore, even at fatty acid concentrations twofold higher than those used in the experiments, no loss in membrane protein was observed. It was shown previously that bovine serum albumin can reverse the inhibitory action of endogenously generated (phospholipase-catalyzed), but not added, fatty acids (Lin and Simon, 1978).

Considering a sequestration of opioid receptors in the membrane (Schwyzer, 1986) and the putative role of membrane in modulating receptor-ligand association (Sargent and Schwyzer, 1986), perturbations of this microenvironment by the fatty acid-lipid interactions outlined above are likely to selectively influence opioid ligand binding. Support for this postulate was provided by our results with the $\mu$ - and $\delta$-selective opioids DAMGO and DPDPE (Clark et al., 1988), and the nonselective antagonist naltrexone (Gillan et al., 1980). In contrast to the milder effects on the $\mu$-receptor, the fatty acid treatment of membranes virtually eliminated the saturable binding of $\left[{ }^{3} \mathrm{H}\right] \mathrm{DPDPE}$. Because the $\mu$ and $\delta$-receptors are apparently localized in an anionic and cationic membrane environment, respectively (Sargent et al., 1988; Schiller et al., 1989), the carboxyl groups of the fatty acids should interact preferentially with that microenvironment of the lipid bilayer containing the binding sites for $\left[{ }^{3} \mathrm{H}\right]$ DPDPE. Furthermore, by influencing the degree of ionization of the carboxyl groups, the local $\mathrm{pH}$ could thereby have a modulating role (Hauser et al., 1979). In this respect, it is of interest to note the differential effect of fatty acids on the two binding components of $\left[{ }^{3} \mathrm{H}\right]$ naltrexone. Considering the observations that low-affinity binding of this antagonist (Remmers and Medzihradsky, unpublished observations) reflects its interaction with the $\delta$-opioid receptor, the effect of $c i s$-vaccenic acid (Table 2) could reflect the preferential targeting of the $\delta$-receptor by fatty acid action also observed with agonist binding (Fig. 4 and Table 1). The molecular reasons for the preferential inhibition by fatty acids of agonist binding and for the protective effect of $\mathrm{NaCl}$ against inhibition of antagonist binding are presently unclear.

It is plausible to suggest that the modulation of opioid receptors by fatty acids reported herein may have a physiological role in the action of opioids. Changes in circulating fatty acid profiles induced by diet, aging, or pathophysiological developments may alter the interaction of opioid receptors with their endogenous opioids and, thus, affect the manifold processes involving these compounds. As shown in this study, depending on the fatty acid profile, a differentiated response in opioid receptor function can be expected. Cellular regulation by unsaturated fatty acids has been proposed on the basis of their stimulation of calcium-dependent protein kinase (McPhail et al., 1984) and direct activation of potassium channels (Ordway et al., 1989).

Acknowledgment: The advice and technical assistance of Dan F. Lazar in applying the GLC analysis of fatty acids are gratefully acknowledged. The consultations with Dr. W. Erickson and Ms. K. Welch from the Statistical Research Laboratory, University of Michigan, have been especially valuable. We thank Ms. Becky McLaughlin for expert secretarial assistance in preparing the manuscript. This work was supported in part by USPHS grants DA04087 and GM07767 (Pharmacological Sciences Training Grant to A.E.R.).

\section{REFERENCES}

Abood L. G., Butler M., and Reynolds D. (1980) Effect of calcium and physical state of neural membranes on phosphatidylserine requirement for opioid binding. Mol. Pharmacol. 17, 290-294.

Aloia R. C., Curtain C. C., and Gordon L. M., eds (1988) Physiological Regulation of Membrane Fluidity. Alan R. Liss, Inc., New York.

Ben-Arie N., Gileadi C., and Schramm M. (1988) Interaction of the $\beta$-adrenergic receptor with $G_{s}$ following delipidation. Specific lipid requirements for $\mathrm{G}_{\mathrm{s}}$ activation and GTPase function. Eur. J. Pharmacol. 176, 649-654.

Bradford M. M. (1976) A rapid and sensitive method for the quantitation of microgram quantities of protein utilizing the principle of protein-dye binding. Anal. Biochem. 72, 248-254.

Cahill A. L. and Medzihradsky F. (1976) Interaction of central nervous system drugs with synaptosomal transport processes. Biochem. Pharmacol. 25, 2257-2264.

Carruthers A. and Melchior D. L. (1986) How bilayer lipids affect membrane protein activity. Trends Biochem. Sci. 11, 331-335.

Carruthers A. and Melchior D. L. (1988) Role of the bilayer lipids in governing membrane transport processes, in Lipid Domains and the Relationship to Membrane Function (Aloia R. C., Curtain C. C., and Gordon L. M., eds), pp. 201-225. Alan R. Liss, Inc., New York.

Clark M. J., Carter B. D., and Medzihradsky F. (1988) Selectivity of ligand binding to opioid receptors in brain membranes from the rat, monkey and guinea pig. Eur. J. Pharmacol. 148, 343-351.

Fischel S. V. and Medzihradsky F. (1981) Scatchard analysis of opiate receptor binding. Mol. Pharmacol. 20, 269-279.

Gillan M. G. C., Kosterlitz H. W., and Paterson S. J. (1980) Com- 
parison of the binding characteristics of tritiated opiates and opioid peptides. Br. J. Pharmacol. 70, 481-490.

Hasegawa J.-I., Loh H. H., and Lee N. M. (1987) Lipid requirement for $\mu$ opioid receptor binding. J. Neurochem. 49, 1007-1012.

Hauser H., Guyer W., and Howell K. (1979) Lateral distribution of negatively charged lipids in lecithin membranes. Clustering of fatty acids. Biochemistry 18, 3285-3291.

Ho W. K. K. and Cox B. M. (1982) Reduction of opioid binding in neuroblastoma $\times$ glioma cells grown in medium containing unsaturated fatty acids. Biochim. Biophys. Acta 688, $211-217$.

Karnovsky M. J., Kleinfield A. M., Hoover R. L., and Klausner R. D. (1982) The concept of lipid domains in membranes. $J$. Cell Biol. 94, 1-6.

Kates M. and Manson L. A. (1984) Membrane fluidity. Plenum Press, New York.

Kuhry J.-G., Fonteneau P., Duportail G., Maechling C., and Laustriat G. (1983) TMA-DPH: a suitable fluorescence polarization probe for specific plasma membrane fluidity studies in intact living cells. Cell Biophys. 5, 129-140.

Law P. Y., Griffen M. T., Koehler J. E., and Loh H. H. (1983) Attenuation of enkephalin activity in neuroblastoma $\times$ glioma NG108-15 hybrid cells by phospholipases. $J$. Neurochem. 40, 267-275.

Lazar D. F. and Medzihradsky F. (1990) Differential inhibition of delta opiate binding and low $K_{\mathrm{m}}$ GTPase stimulation by phospholipase $\mathrm{A}_{2}$ treatment. Prog. Clin. Biol. Res. 328, 113-116.

Lin H.-K. and Simon E. J. (1978) Phospholipase A inhibition of opiate receptor binding can be reversed by albumin. Nature 271, 383-384.

Lowry O. H., Rosebrough N. J., Farr A. L., and Randall R. J. (1951) Protein measurement with the Folin phenol reagent. J. Biol. Chem. 193, 265-275.

McGee R. Jr. and Kenimer J. G. (1982) The effects of exposure to unsaturated fatty acids on opiate receptors, prostaglandin $E_{1}$ receptors, and adenylate cyclase activity of neuroblastoma $\times$ glioma hybrid cells. Mol. Pharmacol. 22, 360-368.

McOsker C. C., Weiland G. A., and Zilversmit D. B. (1983) Inhibition of hormone-stimulated adenylate cyclase activity after altering turkey erythrocyte phospholipid composition with a nonspecific lipid transfer protein. J. Biol. Chem. 258, 13017-13026.

McPhail L. C., Clayton C. C., and Snyderman R. (1984) A potential second messenger role for unsaturated fatty acids: activation of $\mathrm{Ca}^{2+}$-dependent protein kinase. Science 224, 622-625.

Medzihradsky F. (1989) Modulation of opioid receptor mechanisms by membrane lipids: an investigative approach. Adv. Biosci. 75, 41-44.

Morrison W. R. and Smith L. M. (1964) Preparation of fatty acid methyl esters and dimethylacetals from lipids with boron fluoride-methanol. J. Lipid Res. 5, 600-608.

Ordway R. W., Walsh J. V., and Singer J. J. (1989) Arachidonic acid and other fatty acids directly activate potassium channels in smooth muscle cells. Science 244, 1176-1179.

Orly J. and Schramm M. (1975) Fatty acids as modulators of membrane function: catecholamine activated adenylate cyclase of the turkey erythrocyte. Proc. Natl. Acad. Sci. USA 72, 34333437.

Ortiz A. and Gomez-Fernandez J. C. (1987) A differential scanning calorimetry study of the interaction of free fatty acids with phospholipid membranes. Chem. Phys. Lipids 45, 75-91.

Radin N. (1969) Preparation of lipid extracts, in Methods in Enzymology, Vol. XIV (Lowenstein J., ed.), pp. 245-254. Academic Press, New York.

Remmers A. E. and Medzihradsky F. (1987) Modulation of ligand binding to opioid receptors by membrane lipids. Abstracts, International Narcotics Research Conference, Adelaide, Australia.

Rimon G., Hanski E., Braun S., and Levitzki A. (1978) Mode of coupling between hormone receptors and adenylate cyclase elucidated by modulation of membrane fluidity. Nature 276, 394396.

Sargent D. F. and Schwyzer R. (1986) Membrane lipid phase as catalyst for peptide-receptor interactions. Proc. Natl. Acad. Sci. USA $83,5774-5778$.

Sargent D. F., Bean J. W., and Schwyzer R. (1988) Conformation and orientation of regulatory peptides on lipid membranes. Key to the molecular mechanism of receptor selection. Biophys. Chem. 31, 183-193.

Schiller P. W., Nguyen T. M.-D., Chung N. N., and Lemieux C. (1989) Dermorphin analogues carrying an increased positive net charge in their "message" domain display extremely high $\mu$ opioid receptor selectivity. J. Med. Chem. 32, 698-703.

Schwyzer R. (1986) Molecular mechanism of opioid receptor selection. Biochemistry 25, 6335-6342.

Seifert R., Schachtele C., Rosenthal W., and Schultz G. (1988) Activation of protein kinase $C$ by cis- and trans-fatty acids and its potentiation by diacylglycerol. Biochem. Biophys. Res. Commun. $154,20-26$.

Shinitzky M. (1984) Physiology of Membrane Fluidity, Vol. I, chapter 1. CRC Press, Inc., Boca Raton, Florida.

Shinitzky M. and Barenholz Y. (1978) Fluidity parameters of lipid regions determined by fluorescence polarization. Biochim. Biophys. Acta 515, 367-394.

Stubbs C. D. and Smith A. D. (1984) The modification of mammalian membrane polyunsaturated fatty acid composition in relation to membrane fluidity and function. Biochim. Biophys. Acta 779, 89-137.

Werling L. L., Puttfarcken P. S., and Cox B. M. (1988) Multiple agonist-affinity states of opioid receptors: regulation of binding by guanyl nucleotides in guinea pig cortical, NG108-15, and $7314 \mathrm{c}$ cell membranes. Mol. Pharmacol. 33, 423-451.

Wilkinson L. (1988) SYSTAT: The System for Statistics. SYSTAT Inc., Evanston, Illinois. 